(c) American Dairy Science Association, 2006.

\title{
Exposure to Long-Day Photoperiod Prepubertally May Increase Milk Yield in First-Lactation Cows
}

\author{
A. G. Rius and G. E. Dahl ${ }^{1}$ \\ Department of Animal Sciences, University of Illinois, Urbana 61801
}

\begin{abstract}
Exposure to a long-day photoperiod (LDPP) increases mammary and lean growth in heifers relative to a short day (SDPP). Whether these effects influence milk yield, however, is unknown. To test the hypothesis that prepubertal long-day exposure would increase milk production, we assigned prepubertal heifers to LDPP (16 $\mathrm{h}$ of light:8 h of dark; $\mathrm{n}=16$ ) or SDPP ( $8 \mathrm{~h}$ of light:16 $\mathrm{h}$ of dark; $\mathrm{n}=16$ ) until the onset of puberty. At puberty, heifers were commingled and housed under natural photoperiodic conditions and standard nutritional management for dairy heifers. Heifers were bred according to body weight $(\mathrm{BW}=385 \mathrm{~kg})$ and withers height $(\mathrm{WH}=$ $132 \mathrm{~cm}$ ). At parturition, BW, WH, and hip height were evaluated. Analysis of Dairy Herd Improvement Association records was used to evaluate milk yield, milk components, and somatic cell scores. Relative to SDPP $(\mathrm{n}=12)$, heifers on LDPP $(\mathrm{n}=10)$ had greater WH (by $2.4 \mathrm{~cm}$ ) and BW at calving (by $55 \mathrm{~kg}$ ). Compared with heifers housed under SDPP, LDPP heifers tended to produce more milk (750 kg of 305-d projected fat-corrected milk) during the first lactation. Relative to SDPP, prepubertal heifers exposed to LDPP during the prepubertal growth phase were taller and heavier at parturition, and tended to produce more milk during their first lactation.
\end{abstract}

Key words: photoperiod, milk yield, prepubertal heifer

\section{INTRODUCTION}

Rapid rearing of replacement dairy heifers to decrease age at first calving is potentially advantageous to produce revenue (i.e., milk) at a younger age. Heifers calving at younger ages, however, may have diminished milk yield (Gardner et al., 1977; Hoffman et al., 1996; Sejrsen and Purup, 1997), which appears to be related to the high energy intake required to achieve appropriate body size for breeding at an earlier age (Lammers et al., 1999; Sejrsen et al., 2000). Sejrsen and Purup

Received November 14, 2005.

Accepted January 10, 2006.

${ }^{1}$ Corresponding author: gdahl@uiuc.edu
(1997) and Sejrsen et al. (2000) observed that highenergy consumption impaired mammary gland growth in prepubertal heifers. This detrimental effect of a high plane of nutrition seems to be associated with prepubertal rather than postpubertal growth (Sejrsen and Purup, 1997). The assumption generally has been made that decreased parenchymal tissue of the mammary gland at puberty reduces lifetime milk production; however, this relationship has not been sufficiently demonstrated.

Previous research with dairy heifers indicates that photoperiod manipulation offers a management tool to enhance lean growth and accelerate puberty (Hansen et al., 1983; Petitclerc et al., 1985; Schillo et al., 1992). Photoperiod, specifically long days, also promotes mammary parenchymal growth before and after puberty (Petitclerc et al., 1985). Therefore, prepubertal photoperiod manipulation emerges as a potential noninvasive technique to promote lean growth and accelerate the onset of puberty without potential negative consequences on mammary growth. However, effect of photoperiod manipulation during the prepubertal period on subsequent lactation has not been determined.

The primary objective of this study was to evaluate the effect of long-day photoperiods in prepubertal heifers on first-lactation milk yield. Given the potential negative interaction of rapid body growth and milk yield, the second objective was to determine if age of puberty and skeletal growth at calving could be decreased and increased, respectively, by prepubertal exposure to long-day photoperiod.

\section{MATERIALS AND METHODS}

Thirty-two weaned calves ( $86 \pm 2 \mathrm{~d}$ of age; $\mathrm{BW}=106.2$ $\pm 17.3 \mathrm{~kg}$ ) were assigned to a randomized complete design consisting of a $2 \times 2$ factorial arrangement of 4 treatments until the onset of puberty. Puberty was confirmed by circulating progesterone concentrations in excess of $1 \mathrm{ng} / \mathrm{mL}$, as shown in Rius et al. (2005). Briefly, the treatments were photoperiod [long-day photoperiod (LDPP, $16 \mathrm{~h}$ light:8 $\mathrm{h}$ dark) or short-day photoperiod (SDPP), $8 \mathrm{~h}$ light:16 h dark] and diet (control or RUP-supplemented diet). Metal halide lamps were used to provide light at an intensity of approximately 
$350 \mathrm{~lx}$ at the eye level of calves. Protein content of each diet was balanced to $16 \%$ according to NRC (2001) recommendations. At the onset of puberty, heifers were removed from experimental treatments and housed under a natural photoperiod and regular farm management during the breeding period and gestation. Initial exposure to the treatments occurred after weaning between October 2001 and January 2002. The heifers returned to natural photoperiod after attainment of puberty during the summer and fall of 2002 .

Heifers were bred when they met the dual criteria of $132 \mathrm{~cm}$ of withers height (WH) and $385 \mathrm{~kg}$ of BW. These breeding criteria were chosen to allow heifers to have at least 3 estrous cycles before synchronization of estrus. When an individual heifer met those criteria, progesterone-releasing intravaginal CIDR inserts (InterAg, Hamilton, New Zealand) were applied for $7 \mathrm{~d}$ to synchronize estrus. On d 6, $25 \mathrm{mg}$ of $\mathrm{PGF}_{2 \alpha}$ (Lutalyse, Pfizer Animal Health, New York, NY) were injected, and on d 8 and 9, heifers were watched for estrus and inseminated. Semen from 2 sires selected for calving ease was used for AI of all the heifers. Semen from each sire was assigned evenly among treatments. Pregnancy was confirmed 30 to $35 \mathrm{~d}$ after AI by palpation per rectum. Nonpregnant heifers were resynchronized using similar procedures to those described above. Heifers were allowed 5 artificial services before exposure to a bull for natural service. In the present experiment, calving period encompassed fall and winter months of 2004. Hip height (HH) and WH were measured $15 \mathrm{~d}$ before the date of projected parturition, whereas BW was measured $15 \mathrm{~d}$ before the date of projected parturition, and $2 \mathrm{~d}$ after calving. During the first $45 \mathrm{~d}$ postpartum, experimental heifers (now first-lactation cows) were managed in a tie stall barn, fed a common diet, and exposed to natural photoperiodic conditions that limited exposure to supplemental light to less than a total of $12 \mathrm{~h} / \mathrm{d}$. An ad libitum TMR (corn silage, alfalfa haylage, ground corn, cotton seed, soyhulls, and mineral-vitamin supplement) was fed according to NRC (2001) requirements for the first-lactation cow. After $45 \mathrm{~d}$ postpartum, cows were moved to free-stall housing, fed the aforementioned diet, and exposed to natural photoperiodic conditions. Animals were milked twice daily during lactation and DHIA records were used to analyze milk yield and composition (Table 1). Animals began bST at 100 DIM in pairs according to treatment; that is, one LDPP and one SDPP animal began simultaneously.

\section{Statistical Analyses}

Statistical analyses were performed using SAS (SAS Inst. Inc., Cary, NC). All dependent variables were tested for normality using the UNIVARIATE procedure of SAS. The MIXED procedure of SAS was used to analyze estimated means of milk yield from DHIA records. The model included time in the REPEATED statement (test day), the fixed effects of photoperiod, diet, and the random effects of heifer and all possible interactions. Each heifer was a subject of the REPEATED measures statement and was nested within treatment. The variance covariance structure used in the model was autoregressive 1 based on best-fit statistic using Akaike's information criterion (AIC) for the body growth analysis. Analyses of BW, WH, and $\mathrm{HH}$ included fixed effects of photoperiod, diet, and the random effect of heifer and all possible interactions. No significant effect of dietary treatment was detected for the variables analyzed in the present study. Because diet was not significant in the initial analysis, it was removed from the final model. A number of heifers suffered health problems before or during the transition into lactation, including abortion $(n=1)$, left displaced abomasum $(n=3)$, mastitis $(n=$ $3)$, or bovine viral diarrhea $(n=1)$. Data from those cows were excluded from analyses. An additional 2 heifers were removed from the study before breeding. Records from 22 cows were available for analysis through 5 mo of lactation.

\section{RESULTS AND DISCUSSION}

To our knowledge this is the first report testing the effect of LDPP in prepubertal heifers on first-lactation milk yield. Due to the small number of heifers assigned to each treatment, some caution must be used in the interpretation of the results. Relative to SDPP, LDPP heifers tended $(P<0.10)$ to produce more milk during the first 5 DHIA milk test days as well as more ECM (Figure 1). A similar increment was found in projected 305-d fat corrected milk; however, no significant differences were detected for peak milk, actual projected 305d milk, mature equivalent ECM, lactation average SCS, or average SCC (Table 1).

Age at calving did not differ between treatments (Table 1); however, LDPP heifers were numerically younger at calving, suggesting that breeding may be successful at a younger age and lower BW without limiting skeletal growth and milk yield at first lactation. Heifers exposed to LDPP at weaning until the onset of puberty (i.e., during the allometric growth of the mammary gland) that tended to produce more milk during the initial lactation had greater $(P<0.05) \mathrm{BW}$ and WH before calving, and tended $(P<0.08)$ to have greater $\mathrm{HH}$ before calving.

Although mammary growth was not measured in this study, previous work indicates that prepubertal exposure to LDPP increases mammary parenchyma accu- 
Table 1. Analysis of variance including mean squares (MS) and mean comparisons of various production traits of heifers exposed to short- or long-day photoperiod during the prepubertal growth stage

\begin{tabular}{|c|c|c|c|c|c|}
\hline \multirow[b]{2}{*}{ Trait } & \multicolumn{2}{|c|}{ Photoperiod treatment ${ }^{1}$} & \multirow{2}{*}{$\begin{array}{l}\text { Error } \\
\text { MS }\end{array}$} & \multirow{2}{*}{$\begin{array}{l}\text { Treatment } \\
\text { MS }\end{array}$} & \multirow[b]{2}{*}{$P$-value } \\
\hline & $\operatorname{SDPP}(\mathrm{n}=12)$ & $\operatorname{LDPP}(\mathrm{n}=10)$ & & & \\
\hline Peak milk, kg & $33.2 \pm 1.4$ & $33.7 \pm 1.4$ & 12.9 & 0.6 & 0.83 \\
\hline Projected 305 actual milk, kg & $9,020 \pm 273$ & $9,428 \pm 273$ & 828,937 & 748,763 & 0.30 \\
\hline Projected 305 FCM, kg & $9,477 \pm 259$ & $10,227 \pm 299$ & 538,282 & $1,930,607$ & 0.08 \\
\hline Projected 305 ECM, kg & $9,367 \pm 250$ & $10,044 \pm 288$ & 500,641 & $1,572,632$ & 0.10 \\
\hline Projected $305 \mathrm{ME}^{2} \mathrm{ECM}, \mathrm{kg}$ & $11,853 \pm 463$ & $12,754 \pm 535$ & $1,720,464$ & $2,785,094$ & 0.22 \\
\hline Lactation average SCS & $2.8 \pm 0.5$ & $3.0 \pm 0.5$ & 1.7 & 0.2 & 0.72 \\
\hline Lactation average SCC & $109 \pm 53$ & $184 \pm 62$ & 23,114 & 19,242 & 0.37 \\
\hline Age at calving, mo & $24.3 \pm 1.1$ & $23.1 \pm 1.1$ & 115.2 & 2.2 & 0.49 \\
\hline BW before calving, $\mathrm{kg}$ & $637 \pm 17$ & $692 \pm 17$ & 1,912 & 9,218 & 0.05 \\
\hline BW after calving, kg & $603 \pm 22$ & $641 \pm 22$ & 3,402 & 5,076 & 0.24 \\
\hline Withers height before calving, cm & $140.7 \pm 0.8$ & $143.1 \pm 0.8$ & 4.3 & 19.4 & 0.05 \\
\hline Hip height before calving, $\mathrm{cm}$ & $143.8 \pm 1.0$ & $146.6 \pm 1.0$ & 6.3 & 24.0 & 0.08 \\
\hline
\end{tabular}

${ }^{1}$ Long day (LDPP, $16 \mathrm{~h}$ of light) and short day (SDPP, $8 \mathrm{~h}$ of light).

${ }^{2}$ Mature equivalent.

mulation in heifers relative to SDPP (Petitclerc et al., 1985). Given the positive role of prolactin in mammary growth and development (Tucker, 2000), the increase in circulating prolactin under LDPP offers a potential mechanism to explain the increase in parenchyma content. The LDPP-exposed heifers in this study had greater prolactin than those on SDPP (Rius et al., 2005). In addition, circulating IGF-I also increases under LDPP in heifers (Spicer et al., 1994), cows (Dahl et al., 1997), and steers (Kendall et al., 2003). The relative importance of IGF-I to mammary growth, however, is equivocal based on work of Plath-Gabler et al. (2001), in which virgin heifers had limited expression of IGFI, IGF-I receptor, and IGF binding proteins in mammary tissue.

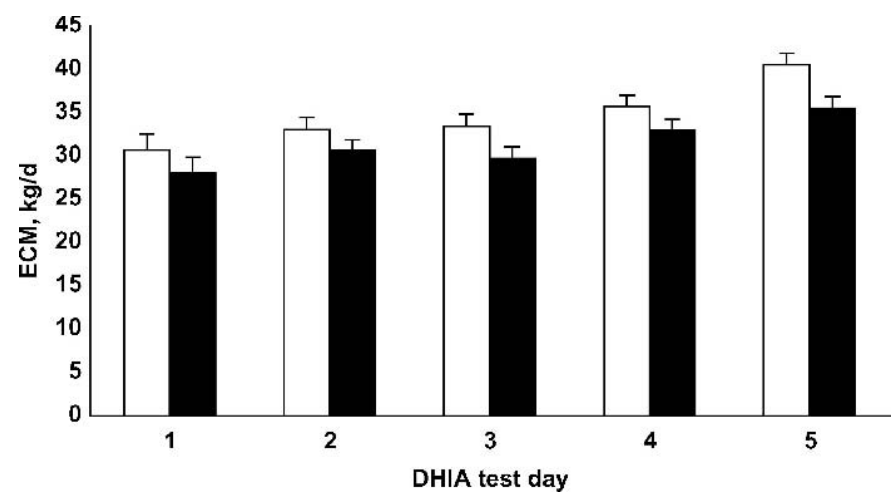

Figure 1. Energy-corrected milk of test-day average in first-lactation cows exposed as heifers to long-day photoperiod (LDPP, $16 \mathrm{~h}$ of light; open bars; $\mathrm{n}=10$ ) or short-day photoperiod (SDPP, $8 \mathrm{~h}$ of light; solid bars; $n=12$ ) from weaning until puberty. Relative to SDPP, LDPP animals tended $(P<0.10)$ to produce more ECM during each of the first 5 mo of lactation.
Finally, the increase in $\mathrm{HH}$ and possible increase in $\mathrm{WH}$ at parturition when heifers are exposed to LDPP prepubertally relative to SDPP cannot be discounted as affecting milk yield. Indeed, Heinrichs and Hargrove (1987) demonstrated that WH has a greater correlation with milk yield in the first lactation than does BW. Because LDPP results in more rapid growth and higher ultimate stature compared with SDPP (Rius et al., 2005), observation of potentially greater milk yield is perhaps not surprising. Regardless of the mechanism, the present study is the first to establish that the prepubertal treatment with LDPP that enhances lean body growth also may improve milk yield during the first lactation. Moreover, the observation that prepubertal heifers exposed to LDPP tended to have greater milk yield in the first lactation supports the concept that prepubertal growth may be accelerated without impairment of ultimate mammary gland function.

\section{REFERENCES}

Dahl, G. E., T. H. Elsasser, A. V. Capuco, R. A. Erdman, and R. R. Peters. 1997. Effects of long day photoperiod on milk yield and circulating insulin-like growth factor-1. J. Dairy Sci. 80:27842789.

Gardner, R. W., J. D. Schum, and L. G. Vargus. 1977. Accelerated growth and early breeding in Holstein heifers. J. Dairy Sci. 60:1941-1948.

Hansen, P. J., L. A. Kamwanja, and E. R. Hauser. 1983. Photoperiod influences age at puberty of heifers. J. Anim. Sci. 57:985-992.

Heinrichs, A. J., and G. L. Hargrove. 1987. Standards of weight and height for Holstein heifers. J. Dairy Sci. 70:653-660.

Hoffman, P. C., N. M. Brehm, S. G. Price, and A. Prill-Adams. 1996. Effect of accelerated postpubertal growth and early calving on lactation performance in primiparous Holstein heifers. J. Dairy Sci. 79:2024-2031.

Kendall, P. E., T. L. Auchtung, K. S. Swanson, R. P. Radcliff, M. C. Lucy, J. K. Drackley, and G. E. Dahl. 2003. Effect of photoperiod on hepatic growth hormone receptor $1 \mathrm{~A}$ expression in steer calves. J. Anim. Sci. 81:1440-1446. 
Lammers, B. P., A. J. Heinrichs, and R. S. Kensinger. 1999. The effects of accelerated growth rates and estrogen implants in prepubertal Holstein heifers on estimates of mammary development and subsequent reproduction and milk production. J. Dairy Sci. 82:1753-1764.

NRC. 2001. Nutrient Requirements of Dairy Cattle. 7th rev. ed. Natl. Acad. Sci., Washington, DC.

Petitclerc, D., R. D. Kineman, S. A. Zinn, and H. A. Tucker. 1985. Mammary growth response of Holstein heifers to photoperiod. J. Dairy Sci. 68:86-90.

Plath-Gabler, A., C. Gabler, F. Sinowatz, B. Berisha, and D. Schams. 2001. The expression of the IGF family and GH receptor in the bovine mammary gland. J. Endocrinol. 168:39-48.

Rius, A. G., A. V. Capuco, E. Connor, P. K. Kendall, T. L. Auchtung, and G. E. Dahl. 2005. Long day photoperiod that enhances puberty does not limit body growth in Holstein heifer. J. Dairy Sci. 88:4356-4365.
Schillo, K. K., J. B. Hall, and S. M. Hileman. 1992. Effects of nutrition and season on the onset of puberty in the beef heifer. J. Anim. Sci. 70:3994-4005.

Sejrsen, K., and S. Purup. 1997. Influence of prepubertal feeding level on milk yield potential of dairy heifers: A review. J. Anim. Sci. 75:828-835.

Sejrsen, K., S. Purup, M. Vestergaard, and J. Foldager. 2000. High body weight gain and reduced bovine mammary growth: Physiological basis and implications for milk yield potential. Domest. Anim. Endocrinol. 19:93-104.

Spicer, L. J., B. A. Buchanan, L. T. Chapin, and H. A. Tucker. 1994. Effect of 4 months of exposure to various durations of light on serum insulin-like growth factor-1 (IGF-1) in prepubertal Holstein heifers. J. Anim. Sci. 72(Suppl. 1):178. (Abstr.)

Tucker, H. A. 2000. Hormones, mammary growth, and lactation: A 41-year perspective. J. Dairy Sci. 83:874-884. 